\title{
Gastric Cancer Pathologic TNM Finding v6
}

National Cancer Institute

\section{Source}

National Cancer Institute. Gastric Cancer Pathologic TNM Finding v6. NCI Thesaurus. Code C61159.

A pathologic finding about one or more characteristics of gastric cancer, following the rules of the TNM AJCC v6 classification system. 